339.92:005.334(061.1EU:510)

https://doi.org/10.18485/fb_nps.2018.ch1

\title{
Liu Zuokui
}

Viši naučni saradnik i direktor Instituta za evropske studije, Kineska akademija društvenih nauka

\section{Rizici Inicijative „Pojas i put” u izgradnji Evroazijskog ekonomskog koridora}

Sažetak

Rad analizira perspektivu ekonomske saradnje EU i NR Kine, iz ugla potencijalnih rizika koji mogu ugroziti realizaciju Inicijative „Pojas i put“. Polazeći od pretpostavke da privredni prosperitet Kine u velikoj meri zavisi od nesmetanog funkcionisanja evroazijskog ekonomskog koridora, autor u centar analize stavlja sedam glavnih rizika koji se mogu isprečiti na putu uspešnoj realizaciji ovog ambicioznog ekonomskog projekta. Nakon kraćeg uvoda posvećenog opštim informacijama o Inicijativi „Pojas i put“, rad ponaosob analizira svaki od sledećih sedam rizika: rizik od podele ili dezintegracije EU, porast populizma i trgovinskog protekcionizma u SAD i EU, uzajamno sankcionisanje Evrope i Rusije (kao prepreku evroazijskoj trgovinskoj povezanosti), ukrajinsku krizu (kao katalizator geopolitičkih konflikata na tlu Evroazije), problem imigracije i izbeglica, konkurenciju drumskog i pomorskog transporta, konkurenciju Rusije i Kine u izgradnji evroazijskih koridora. U završnom delu rada autor daje preporuke praktičnih politika kojima bi se ovi rizici mogli prevazići.

\section{Ključne reči:}

Pojas i put, EU, NR Kina, evroazijski ekonomski koridor, rizik, populizam, trgovinski protekcionizam, sankcije, kriza u Ukrajini, izbeglička kriza, drumski i pomorski saobraćaj, konkurencija 


\section{OSNOVNI PODACI O EVROAZIJSKOM EKONOMSKOM KORIDORU}

EU / evropsko tržište je oduvek od fundamentalnog značaja za razvoj privrede i trgovine Kine. EU je kineski trgovinski partner broj 1. Kad je reč o bruto domaćem proizvodu (skraćeno „BDP”), EU je najveća privreda u svetu, a SAD i Kina su rangirane kao druga i treća po veličini privrede. Nepotrebno je reći da je saradnja između dve moćne privrede, odnosno saradnja između EU i Kine, od velikog značaja za ekonomski razvoj Kine. Iz tog razloga, Kina je oduvek posvećena izgradnji Evroazijskog ekonomskog koridora, kako bi se olakšala bilateralna trgovina između dve strane.

Postoje uglavnom dva puta trgovine iz Kine u Evropu: jedan je kopneni put nazvan Drugi evroazijski kopneni most ili Novi evroazijski kopneni most; drugi je pomorski put nazvan Kinesko-evropski kopneno-pomorski ekspres prolaz. Kopneni put se fokusira na izgradnju Ekspresnog voza kineskih železnica, što je međunarodni, železnički prevoz kontejnera od Kine do Evrope duž „Pojasa i puta”. Ekspres KŽ je pokrenula kineska železnička korporacija i posluje sa fiksnim linijama, maršrutama, voznim redom i trajanjem čitavog putovanja. Ovo je definitivno važna mogućnost prevoza za produbljivanje ekonomske i trgovinske saradnje između Kine i zemalja duž „Pojasa i puta” i istovremeno ključ za promociju izgradnje Inicijative „Pojas i put”. Kinesko-evropski kopneno-pomorski ekspres prolaz je važan pomorski pravac između Kine i Evrope koji počinje od primorskih gradova na jugu Kine i završava se u luci Pirej u Grčkoj, a vodi preko Sredozemnog mora. Iz Pirejske luke kineski teret se može transportovati direktno u evropsko zaleđe železničkim pravcem Grčka - Makedonija - Srbija - Mađarska. Izgradnja ove kopnene i morske rute postaviće čvrstu osnovu za izgradnju Evroazijskog ekonomskog koridora.

\section{SEDAM RIZIKA U IZGRADNJI EVROAZIJSKOG EKONOMSKOG KORIDORA}

U proteklim godinama, kinesko upravljanje bezbednosnim rizicima na Koridoru u određenoj meri poboljšano je napornim radom. Uprkos tome, „meki" rizici se stalno pojavljuju, što zahteva pravovremenu procenu i odgovor. Ono što autor naglašava u ovom radu jeste da se sigurnosni rizici Koridora ne odnose samo na niz pravih sigurnosnih izazova, već i na neke „meke” rizike sa fokusom na efikasnost poslovanja, kvalitet i opšte okruženje globalne trgovine, itd. 


\section{Prvi rizik: potencijalan rizik od podele ili dezintegracije EU}

Sudeći po trenutnoj situaciji, evropske integracije nemaju zamah i suočavaju se sa povećanim rizikom regresije. Kao jedinstveno, veliko tržište, EU ima ogromnu ulogu u promovisanju povezanosti i trgovinske saradnje između Kine i Evrope i jedan je od glavnih motora za razvoj evropskih i azijskih tržišta. Ako se EU, kao jedinstveno tržište, podeli ili dezintegriše, troškovi saradnje između kineskog i evropskog tržišta će dramatično porasti, što je nepovoljno za implementaciju Inicijative „Pojas i put”.

Iako se podela ili raspad EU smatraju događajem male verovatnoće, to se ipak može dogoditi. Francuski Nacionalni front, koji poziva na odvajanje od EU, proglasio je 2017. za godinu najvećih napora u kampanji za referendum i realizaciju francuskog izlaska iz EU. Ustavni referendum, koji je održan u Italiji u 2016. godini, nije odobren, pa ustavna reforma nije stupila na snagu. Posle toga, Renci je podneo ostavku na mesto premijera, što je stvorilo povoljne uslove za kampanju italijanske populističke partije „Pet zvezda", koja je pozvala ljude na svim društvenim nivoima da se suprotstave izbeglicama i evropskim integracijama. Španska stranka „Možemo” i grčka koalicija radikalne levice dobile su relativno visoku podršku na nacionalnim parlamentarnim izborima u poslednje dve godine. Nemačka populistička partija, Stranka nemačkog izbora (AfD), imala je brz rast, prouzrokujući time izvesne nejasnoće na izborima u Nemačkoj 2017. godine. U samoj EU, stavovi o slabljenju EU i dalje dobijaju na snazi. Dezintegracija EU bila je zabranjena tema za političare, ali je sada već uobičajeno $u$ fokusu njihove pažnje. Donald Tusk, predsednik Evropskog saveta, takođe priznaje da su osećanja kao što su protivljenje Evropskoj uniji, nacionalizam i ksenofobija u EU na visokom nivou. Što je još gore, broj ljudi koji i dalje veruju u politiku integracije oštro pada. Porast populizma i sve veće sumnje u osnovne vrednosti slobode i demokratije takođe su glavni razlozi za zabrinutost. ${ }^{1}$ Zaista, EU je trenutno u jednom od svojih ključnih momenata. Ako sve zemlje članice EU ne upregnu svoje snage, postoji mogućnost da EU prestane da postoji.

\footnotetext{
1 "United we stand, Divided we fall” („Ujedinjeni opstajemo, podeljeni propadamo”), pismo predsednika Donalda Tuska šefovima 27 država ili vlada EU o budućnosti Evrope, http://vvv.consilium.europa.eu/en/press/press-releases/ 2017/01/31-tusk-letter-futureeurope/
} 


\section{Drugi rizik: populizam i trgovinski protekcionizam sve više preovladavaju u Evropi i $S A D$}

U poslednjih nekoliko godina evropski populizam se brzo širi po celoj Evropi, što se ne odnosi samo na duel između najvećih evropskih centara pro EU-establišmenta i njihovih protivnika, već takođe odražava nezapamćenu krizu poverenja sa kojom se susreću evropske integracije. Pitanja kao što su evropska dužnička kriza, izbeglička kriza i Brekzit podstakla su sumnje ljudi u elitu pro-EU-establišmenta. Obični ljudi gotovo nikad nemaju bilo kakvu korist od evropskih integracija. Upravo suprotno, oni su sve više i više nepravedno tretirani. Kao rezultat toga postaju sve više sumnjičavi prema glavnim akterima EU.

Donald Tramp, predstavnik američkog anti EU-establišmenta, inaugurisan je za predsednika SAD 20. januara 2017. godine. Njegova pobeda na predsedničkim izborima zaista odražava okolnost da su mase više naklonjene antiimigraciji i političarima koji izražavaju sumnju u zapadne mejnstrim vrednosti, i da se nadaju da će novi državni lider pronaći bolja rešenja. Međutim, činjenica da je Donald Tramp stupio na vlast dodatno podstiče uspon evropskog desnog populizma.

Rastuća popularnost populizma čini EU konzervativnijom i sa manje vremena i snage za sinergiju saradnje sa Kinom, uključujući i Inicijativu „Pojas i put”. Populizam očigledno zagovara antiglobalizaciju i smatra da zemlje u razvoju, kao što je Kina, moraju da snose neophodnu odgovornost i same se maksimalno posvete aktivnostima otvaranja tržišta u odgovoru na korist koju dobijaju od globalizacije. Štaviše, populizam podstiče EU da štiti svoje tržište i radna mesta. U takvim okolnostima, EU u visokom stepenu glasa za trgovinski protekcionizam i često uvodi antidampinške mere i antisubvencije za proizvode made in China.

Sa promenom odnosa SAD i EU prema globalizaciji, kao i daljem širenju antiglobalizacije, trgovinski protekcionizam će verovatno postati najveći rizik za globalnu ekonomiju u 2017. godini. Poslednjih godina Evropa i Amerika podižu najviše antidamping i antisubvencionih istraga baš protiv Kine. Sredinom 2016. godine, kinesko Ministarstvo trgovine je izvestilo da se širom sveta protiv Kine podiže najveći broj antidamping istraga već 21 godinu zaredom i najviše antisubvencionih istraživanja tokom decenije. Sudeći po stanju stvari početkom 2017. godine, Kina je i dalje glavna meta ovog „dvostrukog anti” trenda, koji su uglavnom započele SAD i EU, prema trgovinskim merama preduzetim u Kini. Ovo je definitivno u suprotnosti sa Inicijativom „Pojas i put” koja promoviše otvorenost, inkluzivnost, slobodnu trgovinu i efikasniju globalizaciju. 


\section{Treći rizik: Uzajamne sankcije između Evrope i Rusije} otežavaju evroazijsku trgovinsku međupovezanost

Evropski savet je, 17. marta 2014. godine, formalno saopštio da će EU usvojiti restriktivne mere protiv akcija koje ugrožavaju teritorijalni integritet Ukrajine za 21 ruskog državljanina, uključujući ograničenja putovanja i zamrzavanje imovine. ${ }^{2}$ Od tada, EU je uvela Rusiji trajne sankcije, a zajedno sa Sjedinjenim Državama pooštrila je postojeće sankcije i dodala više novih. Istovremeno, Rusija je usvojila mere protiv sankcija Evropske unije.

Rusija i zemlje Centralne i Istočne Evrope (ZCIE) su dva važna dela evroazijskog kontinenta. Zbog toga uzajamne sankcije između Evrope i Rusije ozbiljno utiču na međupovezanost trgovine u Evroaziji i izazivaju poremećaje u realizaciji neometane trgovine i izgradnji „Pojasa i puta”. Na primer, zbog sankcija Rusije Evropskoj uniji, Ekspres Kineskih železnica ne može, evroazijskim kopnenim mostom, da dostavi u Kinu poljoprivredne proizvode uvezene iz Poljske. Na makronivou, odgovor na pitanje da li može biti ublažena tenzija između Evrope i Rusije mogao bi da ima dubok uticaj na dalju povezanost Evroazije i napredak u izgradnji Evroazijskog ekonomskog koridora. Za sada, novoizabrani predsednik SAD Donald Tramp ima nameru da relaksira veze sa Rusijom. Pored toga, neke ZCIE takođe žele da EU što pre ukine trgovinske sankcije prema Rusiji. Međutim, mišljenja u okviru EU su podeljena po ovom pitanju. Ako međusobne sankcije između Rusije i EU ostaju nerešene kratkoročno, izgradnja „Pojasa i puta” moraće da se suoči sa rizicima tipa „postoje veze između evroazijskog kontinenta, ali je povezanost slaba".

\section{Četvrti rizik: Kriza u Ukrajini pokrenula je geopolitičke konflikte Evroazije}

Ukrajinska kriza je izbila krajem 2013. i otežala geopolitičke sukobe i tenzije između Rusije i Zapada. Neke ZCIE - Poljska i baltičke države, unapredile su svoju odbranu uvećanjem vojne moći NATO pakta sa ciljem suprotstavljanja Rusiji, a Rusija je odgovorila istom merom. Trenutno su evropske zemlje uglavnom pesimistične prema perspektivi rešavanja krize u Ukrajini. One smatraju da će ukrajinska kriza u kratkom roku postati nezgodna i nerešena evroazijska geopolitička kriza. Uticaj geopolitičkog sukoba na povezanost Evroazije je očigledan jer konstantni sukobi u regionu pogoršavaju

2 „EU usvaja restriktivne mere protiv akcija kojima se ugrožava teritorijalni integritet Ukrajine", Savet Evropske unije, Brisel, 17. mart 2017. godine. http://www.consilium. europa.eu/uedocs/cms_data/docs/pressdata/EN/foraff/141603.pdf 
investiciono okruženje. Neke ZCIE, uključujući i Poljsku, pozivaju Kinu da reši taj geopolitički sukob izvršivši politički pritisak na Rusiju zbog potrebe Kine za promovisanjem Inicijative „Pojas i put”. ${ }^{3}$ Međutim, Kina se neće mešati u unutrašnju i spoljnu politiku Rusije. Osim toga, kriza u Ukrajini nikako nije slučajna, i bilo bi nepravedno zbog nje upirati prstom samo u Rusiju. Na kraju krajeva, kontinuirana ekspanzija Amerike i EU na istok i strateški pritisak na Rusiju takođe izazivaju krizu.

Rat $u$ istočnom delu Ukrajine nastavljen je 31. januara 2017. godine još jednim sukobom. Trenutno, gotovo da nema znakova nekog značajnog ublažavanja evroazijskog geopolitičkog konflikta. S obzirom na to, Inicijativa „Pojas i put” mora da se nastavi i da napreduje, suočavajući se sa geopolitičkim tenzijama.

\section{Peti rizik: Evropa i Balkan su ophrvani problemom imigracije} i izbeglica

Balkan ima ključnu ulogu u izgradnji pomorske rute između Kine i Evrope, ali ovaj region je geopolitički osetljiv i izuzetno ranjiv po pitanju geopolitičke nestabilnosti. Odnosi između nekih zemalja Balkana su problematični i trpe zbog izbegličke krize. Pored toga, u nekim balkanskim zemljama nema ekonomske i socijalne stabilnosti. U međuvremenu, region Balkana je dostupan izbeglicama, i suočen je sa ozbiljnim izazovima njihovog protoka. U Turskoj se stalno dešavaju nasilni, teroristički napadi zbog kojih EU ne može da se osloni na tursku otpornost dotoku izbeglica. Pomorska ruta koja je u izgradnji prolazi kroz mnoge balkanske zemlje, uključujući Grčku, Srbiju, Mađarsku i Makedoniju, a najverovatnije će uključiti i Tursku koja se bori protiv terorizma, izbegličke krize, protivrečnosti etničkih grupa i unutrašnje političke nestabilnosti. Zbog spoljnih pretnji, bezbednost i stabilnost Balkana su u velikoj opasnosti što, zauzvrat, utiče na dostignuti nivo i napredak u izgradnji „Pojasa i puta” u Evroaziji.

\section{Šesti rizik: Konkurencija drumskog i pomorskog transporta}

Kopneno-pomorskim Kina - Evropa ekspres prolazom prevozi se 98\% trgovinske robe Kine i EU. Prolaz čine dve maršrute prekookeanskog transporta: prva polazi od azijskih baznih luka, preko Južnog kineskog mora, kroz tesnac Malaka, preko Indijskog okeana i Crvenog mora, kroz Suecki kanal, preko Sredozemnog mora, kroz Gibraltarski moreuz i preko Atlantskog

\footnotetext{
$3 \quad$ Govor Vitolda Varščikovskog, poljskog ministra spoljnih poslova u Kineskoj akademiji
} društvenih nauka, 25. aprila 2016. godine. 
okeana stiže do evropskih, baznih luka; druga ruta povezuje azijske bazne luke sa evropskim baznim lukama preko Južnog kineskog mora, Indijskog okeana, pored Rta dobre nade, preko Gvinejskog zaliva i Atlantskog okeana. Pomorski prevoz ima nekoliko prednosti, uključujući brzo i jednostavno carinjenje koje zahteva samo dva transportna dokumenta, dozvoljava veliku težinu robe u kontejnerima i ima niske troškove transporta. Mane transporta morem su relativno velike udaljenosti i vreme transporta. ${ }^{4}$ Drumski saobraćaj, uključujući i Ekspres kineskih železnica, vremenski je efikasniji od pomorskog saobraćaja, ali je cena mnogo veća, a procedura carinjenja je složenija.

I drumski i pomorski transport imaju svoje prednosti i slabosti. Neke pošiljke mogu da se dostavljaju bilo kopnenim bilo morskim prevozom, što intenzivira neku vrstu takmičenja između dva načina transporta oko robe za prevoz. Zbog nedovoljne količine robe oduvek postoji takva konkurencija između Ekspresa kineskih železnica i i kopneno-pomorskog Kina - Evropa ekspres prolaza. Iz moje perspektive, ovo pitanje treba rešavati kroz aktivnu koordinaciju vlada i esnafa. Pored toga, saradnja između drumskog transporta i pomorskog transporta je opšti trend u izgradnji koridora Kina - Evropa.

\section{Sedmi rizik: Konkurencija Kine i Rusije u izgradnji evroazijskih koridora}

Kada je reč o izgradnji evroazijskih koridora, Rusija je posvećena razvoju sibirskog koridora, poznatog i po imenu Prvi evroazijski kopneni most. Kina je koncentrisana na eksploataciju novog evroazijskog kopnenog mosta, odnosno Drugog evroazijskog kopnenog mosta. Kao zemlja porekla i distribucije tereta Drugim evroazijskim kopnenim mostom, Kina neće tražiti transport kineske i evropske robe Prvim evroazijskim kopnenim mostom. Drugi evroazijski kopneni most je definitivno interkontinentalni železnički okvir ekonomskog pojasa Put svile.

Prednost Prvog evroazijskog kopnenog mosta je sledeća: za početak, vreme tereta je predvidljivo zbog činjenice da je širina železničkog koloseka u zemljama Zajednice nezavisnih država (ZND) ista kao ona u Finskoj, pa je zamena donjeg podstroja vagona nepotrebna. Drugo, kada se, u luci Vostočni u Nahotki, kontejneri napune teretom može se tačno izračunati vreme dolaska na svaku usputnu stanicu i vreme potrebno za celo putovanje.

$4 \quad$ Siao Jang, Kina - Evropa kopneno-pomorski ekspres prolaz i balkanski neksus logističke mreže „Pojas i put”, Journal of Contemporary International Relations, br. 8, 2015. 
Pored toga, Rusija, Kazahstan i Belorusija su formirale carinsku uniju kako bi pojednostavile proces carinjenja. S druge strane, Drugi evroazijski kopneni most je takođe povoljan i dobro prihvaćen zbog relativno kratke dužine i niske cene železničkog saobraćaja. Konkretno, u poređenju sa Prvim evroazijskim kopnenim mostom, Drugi evroazijski kopneni most skraćuje rastojanje između Kine i Centralne Azije za više od 1.000 kilometara. Takođe, cena međudržavnog prevoza na kratke udaljenosti (oko 1.000 kilometara) relativno je niska.

Rusija oduvek smatra eksploataciju Prvog evroazijskog kopnenog mosta bazičnom, nacionalnom politikom koja ima za cilj ekonomski razvoj Dalekog istoka. Ona ne samo da shvata Drugi evroazijski kopneni most kao glavnu konkurenciju Prvom, već takođe preduzima različite mere da proširi uticaj ruskih železnica u procesu razvoja logistike Azije i Evrope. Prvo, kroz puno korišćenje multilateralnih platformi, kao što je Komisija za železnički transport ZND, Rusija aktivno usmerava zemlje ZND na korišćenje jedinstvenih železničkih standarda, čija osnova je standard ruskih železnica, kako bi monopolizovala tržište železničke opreme u Centralnoj Aziji. Drugo, Rusija je uspostavila „Alijansu širih šina” kroz međunarodni kooperativni mehanizam železnica od 1520 mm širine šina. Na ovoj osnovi, Rusija se udružila sa Kazahstanom i Belorusijom u cilju uspostavljanja zajedničke transportne kompanije, preuzimajući istovremeno azijski deo evroazijskih železnica. Treće, Rusija je predložila projekat osnivanja zajedničke železničke kompanije (Trans-Eurasian Logistics) sa Kinom, Nemačkom i Kazahstanom, kako bi se izgradio, ka Rusiji orijentisan, evroazijski logistički lanac železničkog transporta kontejnera. Sve ove akcije Rusije pojačale su konkurentni pritisak na promociju mogućnosti povezivanja Drugog evroazijskog kopnenog mosta koju vrši Kina. ${ }^{5}$

Kina tek treba da spreči Rusiju da razdvoji teretne vozove na putnom pravcu Kina - Evropa. U stvari, neki od tih teretnih vozova, kao što su oni koji kreću iz severoistočnih delova Kine, putuju Prvim evroazijskim kopnenim mostom, dok drugi putuju Drugim evroazijskim kopnenim mostom. Do sada je jedinstveni identitet teretnih vozova ostvaren samo u nekoliko provincija u Kini, umesto da tako bude u celoj zemlji. Dakle, kompetitivnost oko putnih pravaca transporta i isporuke robe širom zemlje prilično je česta, što omogućava Rusiji da prema Kini usvoji i primeni strategiju „podeli pa vladaj".

Siao Jang, Kina - Evropa kopneno-pomorski ekspres prolaz i balkanski neksus logističke mreže „Pojas i put”, Journal of Contemporary International Relations, br. 8, 2015. 


\section{PREDLOZI POLITIKA}

Ovaj rad nudi niz principijelnih rešenja za neke fundamentalne i urgentne probleme i ozbiljno istražuje mogućnost efikasnih kontramera.

Prvo, makropitanja i mikropitanja treba mudro razmotriti i pravilno ih uravnotežiti. Moramo posvetiti veliku pažnju rizicima u izgradnji evroazijskih koridora, osnažiti istraživački rad s tim u vezi, kako na makronivou tako i na mikronivou, i osmisliti fleksibilne i ciljane mere zasnovane na situaciji u svakoj zemlji i postojećem stanju stvari. Na makronivou, moramo dati veliki značaj evropskim integracijama, evropskom populizmu i trgovinskom protekcionizmu, evroazijskoj geopolitičkoj krizi i izbegličkoj krizi, i uraditi analizu i procenu trgovinskog okruženja i mogućnosti razvoja geopolitike Evroazije i sveta, kako bismo obogatili naše znanje o suzbijanju rizika u vezi sa Inicijativom „Pojas i put”. Na mikronivou, moramo da se fokusiramo na stavove koje zemlje članice EU i zemlje kandidati imaju prema Inicijativi „Pojas i put” i da usvojimo set fleksibilnih mera zasnovanih na stanju svake zemlje. U međuvremenu, moramo jasno da razumemo izazove sa kojima se suočava Inicijativa „Pojas i put”, i obezbedimo ciljana rešenja koja su u skladu sa uslovima specifičnim za svaki pojedinačan izazov.

Drugo, ne treba zanemariti ni planove ni tržište. Kada je reč o nacrtu „Pojasa i puta” u Evroaziji, moramo da naglasimo tržišnu orijentaciju i istovremeno iskoristimo izvršnu vlast na najbolji mogući način. Neki smatraju da izgradnja „Pojasa i puta” neće biti održiva ako je bez tržišne orijentacije, što je diskutabilno. Kako se neoliberalizam susreće sa dilemama i krizama, nacionalna administracija ima sve značajniju ulogu u primeni glavnih strategija. Imajući u vidu kineske nacionalne uslove, moramo dobro da iskoristimo administrativne vlasti, istovremeno stavljajući jak naglasak na fundamentalnu ulogu tržišta, treba u punoj meri da poštujemo planove za dodeljivanje resursa, da udružimo pamet i poboljšamo efikasnost, i da imamo dobar, vrhunski dizajn Inicijative „Pojas i put”. Osim toga, trebalo bi da saznamo teškoće sa kojima se suočava Inicijativa, inovativno prilagodimo metode i aktivno istražimo rešenja, povećamo racionalnost sistema i snabdevanje resursima efikasno kombinujući planove i tržište, kako bismo podstakli Inicijativu „Pojas i put” na pravi način.

Treće, potrebna je razumna konkurencija i efikasna saradnja pomorskog saobraćaja i kopnenog saobraćaja. U procesu izgradnje koridora Kina - Evropa, i pomorski i kopneni saobraćaj imaju i prednosti i slabosti, i treba ih birati na osnovu zahteva isporuke robe, a ne po volji lokalnih vlasti. U cilju održavanja razvoja dvaju načina transporta, trebalo bi da postoji razumna konkurencija i efikasna saradnja između pomorskog saobraćaja 
i kopnenog saobraćaja. Da bi se potpuno iskoristile prednosti kopneno-pomorskog, multimodalnog transporta, treba ne samo promovisati osnovnu ulogu tržišta već i održavati bezbednost kineskih trgovinskih koridora.

Na primer, Ekspres kineskih železnica mogao bi da privuče više tereta visoke dodatne vrednosti koji je dostavljan pomorskim transportom u ograničenom vremenskom roku, kao i vazdušni teret sa dovoljno vremena za isporuku. Morski transport, međutim, treba da se koristi za isporuku tereta sa relativno malom dodatnom vrednošću i dovoljnim vremenom isporuke. Kada je reč o robi koja može da se transportuje bilo pomorskim ili kopnenim saobraćajem, kopneno-pomorski, multimodalni transport je bolji izbor koji vodi razumnoj i efikasnoj podeli rada na evroazijskom tržištu transporta.

Takođe treba napomenuti da je unifikovanje identiteta teretnih vozova samo prvi korak u rešavanju određenih problema u radu Ekspresa kineskih železnica, kao što su niska efikasnost, finansijske subvencije i nedovoljne količine robe za transport. Predstoje veći izazovi kojima treba pristupiti kroz stalnu i sve snažniju koordinaciju između svih vozova unutar Kine i između pomorskog i kopnenog saobraćaja širom sveta.

Četvrto, konkurentnost Kine i zajednički rad sa Rusijom preduslovi su za konsolidaciju strateške saradnje između ovih zemalja. Mogućnost povezivanja trgovine u Evroaziji nije korisna samo za Kinu, već je i u interesu Rusije. Tamo gde se interesi preklapaju postoji žestoka konkurencija. Rusija se takmiči sa Kinom oko koridora Kina - Evropa kako iz ekonomskih tako i iz geopolitičkih interesa. Za takvu vrstu konkurencije, Kina treba da uzme u obzir dominantan uticaj Rusije u Evroaziji. Sve dok postoje zajednički interesi, Kina treba da ima pragmatičan stav kojim bi ojačala učenjem od Rusije i ulaženjem na rusko tržište, nadoknadila slabosti koristeći rusko tržište i postepeno uspostavila čvrsto uporište na evroazijskom tržištu transporta. Na kraju krajeva, veze mogu biti izgrađene samo na osnovu snage, a ne na toleranciji. Snažna konkurentnost je ono što ostvaruje realna partnerstva.

Konačno, treba da prihvatimo rizike i izazove pripremljeni i sa pouzdanjem. Uprkos brojnim poteškoćama i izazovima u izgradnji „Pojasa i puta”, treba uvek da budemo sigurni u tu Inicijativu stalno obogaćujući njenu konotaciju. Implementacija „Pojasa i puta” u Evroaziji, koja je puna opasnosti, sama po sebi je efikasan način širenja temeljnih vrednosti kineskog razvojnog puta i sistema. U uslovima globalnog previranja i sporog ekonomskog rasta, neoliberalizam postepeno gubi trku s populizmom i trgovinskim protekcionizmom koji preovlađuju u zapadnom svetu, što ukazuje na to da se privlačnost zapadnih zemalja, stečena promocijom otvorenosti i slobode, pretvara u sopstvenu suprotnost. Nasuprot tome, Kina 
se suočava sa mogućnostima razvoja kakve se retko sreću. Zbog toga treba da upravljamo spoljašnjim očekivanjima prema Inicijativi „Pojas i put”, da učinimo da se ideje i glas Kine čuju i da se potrudimo da osvojimo bolju poziciju u takmičenju dvaju režima i dveju ideologija. 